\title{
A NEW LOCALITY FOR THE FRAGRANT WATER LILY IN MANITOBA
}

LEONARD J. HUTCHISON, Department of Botany, University of Toronto, Toronto, Ontario. M5S $1 \mathrm{~A} 1$

Southeastern Manitoba is at the western extremity of the Great Lakes-St. Lawrence forest region in Canada. ${ }^{2}$ It is in this area that there are many plant species which are not generally found in the rest of the prairie provinces. Woody species such as the Eastern White Pine (Pinus strobus), Red Pine ( $P$. resinosa), Ground Hemlock (Taxus canadensis) and Horn Hopbeam (Ostrya virginiana) can be found here in addition to herbaceous species such as Wild Ginger (Asarum canadense), Jack-in-the-Pulpit (Arisaema triphyllum) and the Sensitive Fern (Onoclea sensibilis). While many of the plants in this forest region are common throughout their range in eastern North America, a few are considered to be locally rare in Manitoba. One such plant is the Fragrant Water Lily (Nymphaea odorata). ${ }^{4}$

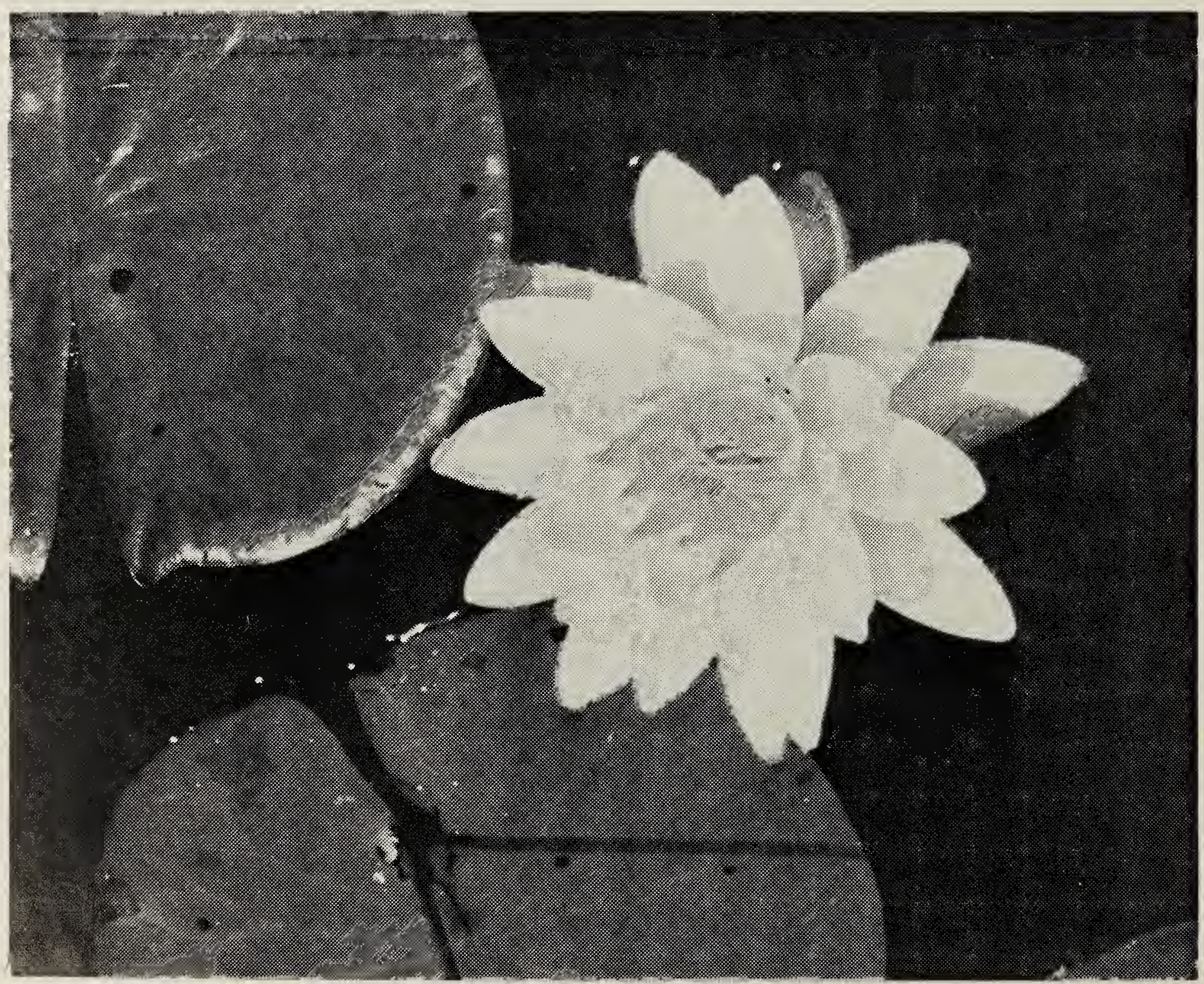

Fragrant Water Lily found in Nopiming Provincial Park 
The two published floras for the province, as well as a herbarium search (Table 1.) have shown that this attractive plant has until now been found only in Whiteshell Provincial Park and its vicinity in southeastern Manitoba. ${ }^{3}$ An exception is a single record for a specimen collected north of Lake Winnipeg. Recently I had the opportunity to collect this species near Black Lake in Nopiming Pro vincial Park, which is situated east of Lake Winnipeg and north of Whiteshell P.P. along the Manitoba Ontario boundary. The collection represents a new locality record for the province.

In the small lakes where this water lily was found growing, it only colonized shallow bays with rocky or sandy bottoms. The more common Small Water LiIy (Nymphaea tetragona ssp. leibergii) and the Yellow Pond Lily (Nuphar variegatum) were also found in this region but appeared to be restricted to slow moving streams and shallow bays with muddy bottoms. Since Manitoba has not been systematically botanised over the years, large gaps exist in our knowledge of plant species distribution. With increased observations and collecting by amateur and professional botanists alike, many plants such as the Fragrant Water Lily may be found to have more extensive distributions within the province. Ultimately, the possibility exists that some of these species may be removed from the list of rare vascular plants for Manitoba.

I would like to thank R.I. Staniforth, G.M. Keleher and K.L. Johnson for access to plant collections, and R.C. Summerbell for reviewing the manuscript.

'LOOMAN,J. and K.F. BEST 1979. Budd's flora of the Canadian prairie provinces. Agric Canada Publ. No. 1662, Ottawa.

${ }^{2}$ ROWE, J.S. 1972. Forest regions of Canada. Can. For. Serv. Publ. No. 1300. Ottawa.

3SCOGGAN, H.l. 1957. Flora of Manitoba. Nat. Mus. of Canada Bull. No. 140, Ottawa.

${ }^{4}$ WHITE, D.J. and K.L JOHNSON 1980. The rare vascular plants of Manitoba. Nat. Mus. of Nat. Sci. Syllogeus No. 27, Ottawa.

Table 1. COLLECTIONS OF FRAGRANT WATER LILY IN MANITOBA HERBARIA

Location

1)Shoal Lake

2) Whiteshell P.P. (West Hawk Lake) (Caddy Lake) (Lily Pond Lake)

3) Lac du Bois

4) Nopiming P.P. (near Black Lake)

5) Minago River, near Hill Lake (North of Lake Winnipeg)

\section{Collector and Date}

C.W. Lowe, July 1920

C.W. Lowe, July 1920

Mrs.A. Simpson, July 1956

Mrs.A. Simpson, 18 Aug.1934

B. Boivin, 26 June 1959

S. Mclnnes, 13 July 1973

K. Essenberg, 12 july 1977

J.D. Johnson, 22 June 1983

G.M. Keleher, 18 Aug. 1982

L.). Hutchison, 10 July 1986

H.J. Scoggan, 17 July 1948
Specimen*

WIN 2755

WIN 2756

MMMN 758

MMMN 755

WIN 2758

MMMN 2866,2868

UWPG 0608

MMMN 13289

WIN 38297

WIN 42909

WIN 2757

* WIN = Herbarium of the Univ. of Manitoba; MMMN = Herbarium of the Manitoba Mus. of Man and Nature; UWPG = Herbarium of the Univ. Of Winnipeg 